\title{
Pathomorphological findings of Mortellaro disease in dairy cattle
}

\author{
Arda Selin TUNÇ ${ }^{1, a, ®}$, Soner ÇAĞATAY ${ }^{2, b}$, Mehmet SAĞLAM ${ }^{3, c}$, Osman KUTSAL $^{1, d}$ \\ ${ }^{1}$ Ankara University, Faculty of Veterinary Medicine, Department of Pathology, Ankara, Turkey; ${ }^{2}$ Near East University, Faculty of \\ Veterinary Medicine, Department of Surgery, Cyprus; ${ }^{3}$ Aksaray University, Faculty of Veterinary Medicine, Department of Surgery, \\ Aksaray, Turkey. \\ aORCID: 0000-0002-4813-7626; bORCID: 0000-0002-7358-4399; ' $O R C I D: 0000-0001-8934-8529$; ${ }^{\mathrm{d} O R C I D: ~ 0000-0003-3599-6867 ~}$
}

Corresponding author: scoskan@ veterinary.ankara.edu.tr

Received date: 23.09.2020 - Accepted date: 21.10.2020

\begin{abstract}
Mortellaro disease is an infection caused by mostly spirochete bacteria in dairy cows, sheep, and goats. The aim of the present study was to define to Mortellaro disease pathomorphologically and immunohistochemically and investigate whether cellcell adhesion connections are lost in cell proliferation. Tissue samples were collected from underfoots of Holstein (n: 6) and Swiss Brown (n: 15) dairy cattle. The sections were stained with hematoxylin-eosin (H\&E) and Warthin-Starry (WS) for isolation of spirochetes histopathologically and with $\beta$-catenin and PCNA primary antibodies immunohistochemically. Histopathologically, number of the cells in the stratum spinosum layer increased excessively, and it gave finger-like extensions to the dermis. Black stained spirochetes were detected among enlarged keratinocytes and inflammatory cells in WS staining. $\beta$-catenin was strongly positive in the cell membranes of epithelial cells in all slides. PCNA also gave positive reaction moderately (n: 18) and strongly (n: 3 ) in nuclei of epithelial cells. It was observed that $\beta$-catenin cell-cell adhesion connections did not impair in the disease, so this is thought to positively affect the prognosis of the disease. The high expression of PCNA showed that the mitotic activity was high and explained the formation of wart-like. As a result, while the disease does not have a poor prognosis, the disease has a negative economic impact, and the economical results of this disease might be much greater than the treatment costs. It is still seen in our country and causes in loss of yield for the economy of country.
\end{abstract}

Keywords: Dairy cattle, digital dermatitis, immunohistochemistry, Mortellaro disease, pathomorphology.

\section{Süt sığırlarında Mortellaro hastalığının patomorfolojik bulguları}

Özet: Mortellaro hastalığı süt sığırlarında, koyunlarda ve keçilerde şekillenen, çoğunlukla spiroket bakterilerinin neden olduğu bir enfeksiyondur. Bu çalışmanın amacı, Mortellaro hastalı̆̆ını patolojik ve immünohistokimyasal olarak tanımlanması ve hücre proliferasyonunda hücre-hücre adezyon bağlantılarının kaybolup kaybolmadığının araştırılmasıdır. Çalışmada Holştayn (n: 6) ve İsviçre Esmeri (n: 15) 1rkı süt sığırlarından ayakların altından doku örnekleri toplandı. Kesitler, histopatolojik olarak hematoksileneozin (H\&E) ve spiroketlerin izolasyonu için Warthin-Starry (WS) ile; immünohistokimyasal olarak da $\beta$-katenin ve PCNA primer antikorları ile boyandı. Histopatolojik olarak stratum spinosum tabakasındaki hücreler aşırı derecede artmıştı ve dermise parmak benzeri uzantılar vermişti. WS boyamasında genişlemiş keratinositler ve yangı hücreleri arasında siyah renkli spiroketler tespit edildi. $\beta$-katenin, tüm olgularda epitel hücrelerinin hücre membranlarında kuvvetli pozitifti. PCNA da epitel hücrelerinin çekirdeklerinde orta derecede (n: 18) ve kuvvetli (n: 3) pozitif reaksiyon verdi. $\beta$-katenin hücre-hücre adezyon bağlantılarının hastalıkta kaybolmadığı gözlendi, bu nedenle bu durumun hastalığın prognozunu olumlu etkilediği düşünülmektedir. PCNA'nın yüksek ekspresyonu, mitotik aktivitenin yüksek olduğunu gösterdi ve siğil benzeri oluşumları açıkladı. Sonuç olarak, hastalık kötü bir prognoza sahip değildir ancak ekonomik kayıpları oldukça yüksektir ve bu nedenle bu hastalığın ekonomik sonuçları tedavi maliyetlerinden çok daha fazla olabilir. Ülkemizde halen görülmektedir ve ülke ekonomisinde verim kaybına neden olmaktadır.

Anahtar sözcükler: Dijital dermatitis, immünohistokimya, Mortellaro hastalı̆̆ı, patomorfoloji, süt sığırı.

\section{Introduction}

Mortellaro disease, also known as digital dermatitis, hairy heel warts, strawberry foot, digital warts or interdigital papillomatosis, is an infection caused by mostly spirochete bacteria. It is mostly characterized by a painful papilloma-like-warts on the heel inducing lameness. Mortellaro disease was reported in dairy cows, sheep, and goats both in Turkey and in the world $(3,4,16$, 19, 32).

The pathogenesis is still not clear. On the other hand, predisposing factors such as shelter, feeding conditions, and season play a major role in the occurrence of the 
disease. The disease brings about discomfort and often severe lameness that decreases milk production, reproductive efficiency, and the health and welfare of the dairy cattle. This situation causes serious economic losses for dairy producers $(6,20,25,29)$.

The macroscopical appearance of the disease could be either ulcerative, erosive, or proliferative and wart-like with papillary growths. Lesions are circular or oval in shape and the skin is usually red in colored $(14,27)$.

Few papers were reported about histopathology and immunohistochemistry of the disease. In previous studies, the researchers reported a thickening of the epidermis with necrosis and hyperkeratosis, ulcer formation, hemorrhage, microabscess foci and infiltration of neutrophils, mononuclear cells, and eosinophils in both the epidermis and dermis in histopathological examinations $(6,9,14,19$, 28).

$\beta$-catenin, also known as Catenin beta-1, is encoded by the CTNNB1 gene. It is so significant for cell adhesion and is chiefly existing in the cell membranes. $\beta$-catenin is related with regulation and link of cell-cell adhesion and gene transcription. $\beta$-catenin also plays an important role in a signaling pathway of progenitor cell proliferation and differentiation $(11,18)$. $\beta$-catenin is used for hyperplasias and many different types of tumors such as mammary, lung, colon, liver $(1,7,11,17,26,30)$.

PCNA, 'proliferating cell nuclear antigen', is a cell cycle protein that acts as a processivity factor for DNA polymerase delta in cells of all eukaryotic species. It is also a DNA clamp. Cell proliferation can be determined by the change in the amount of PCNA within the cell. While PCNA expression increases in G phase, it reaches maximum in $\mathrm{S}$ phase where DNA is duplicated. A decrease in PCNA expression is observed during the transition to the $M$ stage of cleavage. In this way, the positions of the cells in the division cycle can be determined by PCNA expression $(23,31,33)$.

The aim of the present study was to define to Mortellaro disease pathomorphologically and immunohistochemically and investigate whether cell-cell adhesion connections are lost in cell proliferation.

\section{Material and Methods}

Tissue samples: In this study, tissue samples from their underfoots were collected from dairy cattle of Holstein (n: 6) and Swiss Brown (n: 15) breed which were suffering from pain and clinical lameness. These samples were taken from the various regions with lesions under local anesthesia with punch biopsy and were treated with topical oxytetracycline hydrochloride spray and lincomycin hydrochloride soluble powder and then sent for routine diagnosis to the Ankara University Department of Pathology.
Microscopical examinations: The samples were fixed in $10 \%$ neutral buffered formalin, processed routinely, embedded in paraffin, and sectioned at $5 \mu \mathrm{m}$ thickness. The sections were stained with hematoxylineosin (H\&E) and Warthin-Starry (WS) for isolation of spirochetes (21).

Immunohistochemical examinations: After deparaffinization and dehydration were provided, peroxidase activity was removed from the tissues on adhesive slides with $3 \%$ hydrogen peroxide-methanol solution. Antigen retrieval using microwave heating (10 min; $10 \mathrm{mmol} /$ citrate buffer, $\mathrm{pH}$ 6.0) was performed. Nonspecific proteins in tissue were blocked by using a protein blocking solution. All slides were submitted to a Streptavidin Biotin Complex Peroxidase (Strept ABC-P) according to the manufacturer's protocol (Super Sensitive Polymer-HRP Detection System (BioGenex, Fremont, CA, REF: QP300-XAK)). Primary antibodies were selected as $\beta$-catenin (Ready to use, Thermo Fisher Scientific) and PCNA (1:200 dilution, PC10, Thermo Fisher Scientific). The slides were incubated for both primary antibodies for $45 \mathrm{~min}$ at $56^{\circ} \mathrm{C}$ in the oven. As chromogen, 3-Amino-9-Ethylcarbazole (AEC) was used, and slides were counterstained with Mayer's hematoxylin and then coverslipped using an aqueous mounting media. For negative controls, PBS was used instead of each primary antibody. All microscopical areas were evaluated and positivities were picked up from 10 areas at the same magnification. The results were scored as mild, moderate, and strong as $<10 \%, 10-50 \%,>50 \%$, respectively. All results were evaluated under a light microscope (Leica, DM 4000B) and were photographed (Leica DFC-280).

\section{Results}

Clinical findings: After the masses were taken for pathological examination, firstly, they were treated only with topical oxytetracycline hydrochloride spray. After one month, four of 21 cows did not recover, and lincomycin hydrochloride soluble powder was added to the treatment options. So, functional recovery was achieved in all cases and no recurrence of digital dermatitis during a follow up period of 15 months were seen.

Macroscopical findings: All masses appeared as a proliferation of single or multiple cauliflower-like. The masses were from $0.3 \mathrm{~cm}$ to $2 \times 1 \times 0.5 \mathrm{~cm}$ in diameter and had grayish white in color and hard in consistency with lobular in appearance at the cut sections. Some masses had necrotic, ulcerative, and hemorrhagic areas (Figure 1 AB).

Microscopical findings: The keratin layer on the stratum corneum was thickened and included parakeratosis in some area with the retention of nuclei. It 
was noted that the cells increased excessively in the stratum spinosum layer, and it gave finger-like extensions to the dermis. In some areas, microabscesses, ulcers, inflammatory cells, vascularization, degenerative, and necrotic changes in epithelial cells, and proliferation of connective tissue were seen (Figure $2 \mathrm{~A}-\mathrm{C}$ ) and there was also no finding of neoplasia. Visible black stained spirochetes were detected among enlarged keratinocytes and inflammatory cells in WS staining (Figure $2 \mathrm{D}$ ).

Immunohistochemical findings: $\beta$-catenin was strongly positive in the cell membranes of epithelial cells in all slides (Figure 3 A-B). PCNA also gave positive reaction moderately (n: 18) and strongly (n: 3$)$ in nuclei of epithelial cells (Figure 3 C-D).

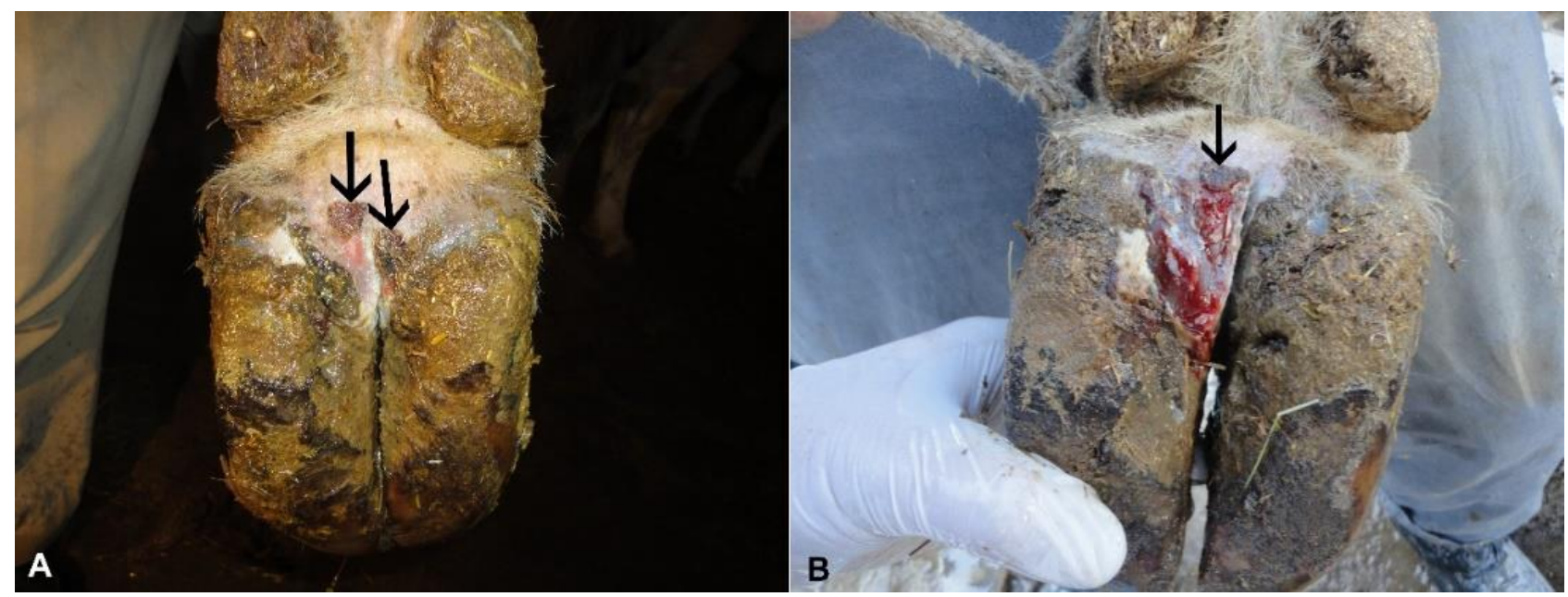

Figure 1. A-B. Gross appearance of papilloma-like-warts (arrows) and necrotic, hemorrhagic, ulcerative areas on the heels.
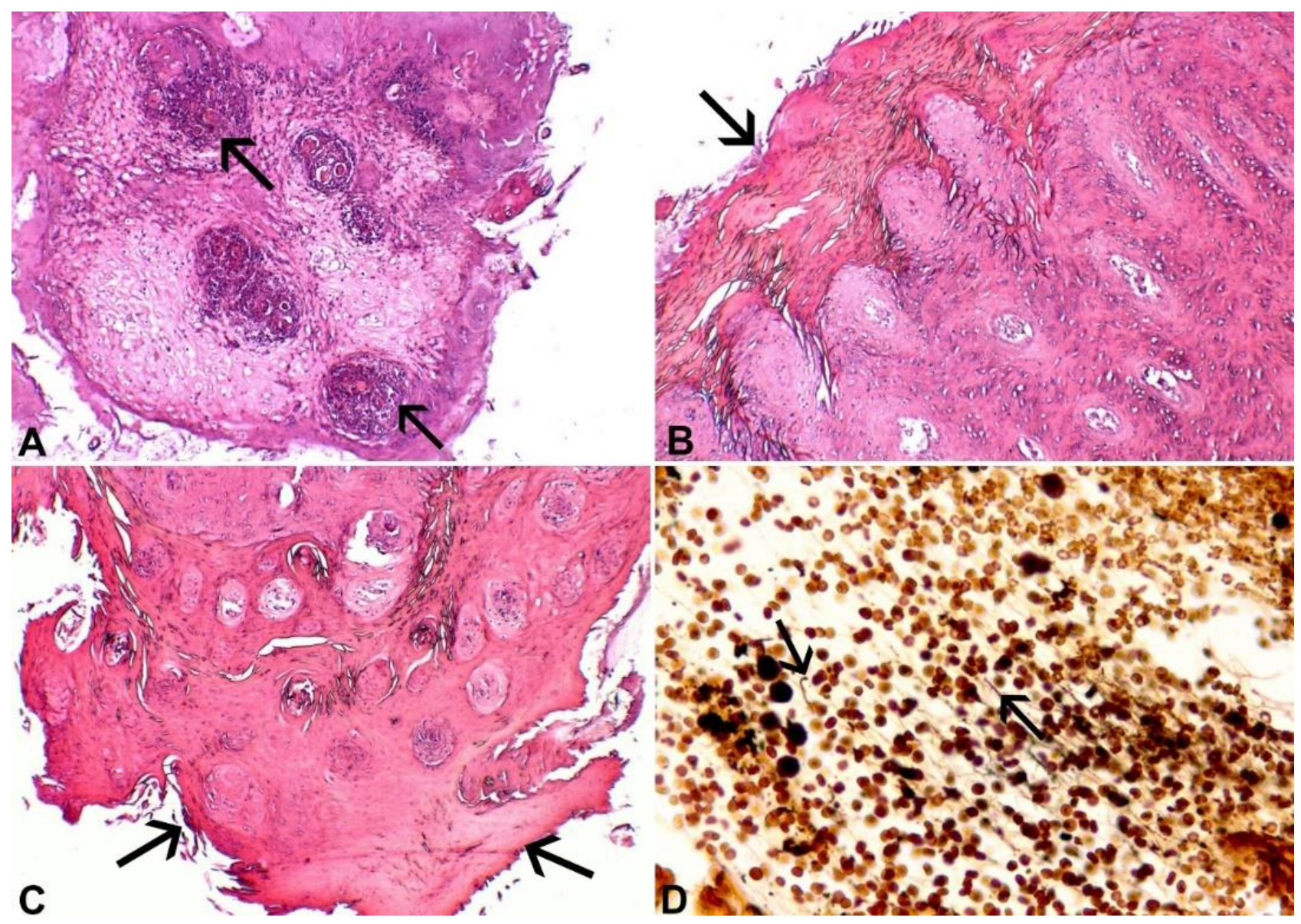

C

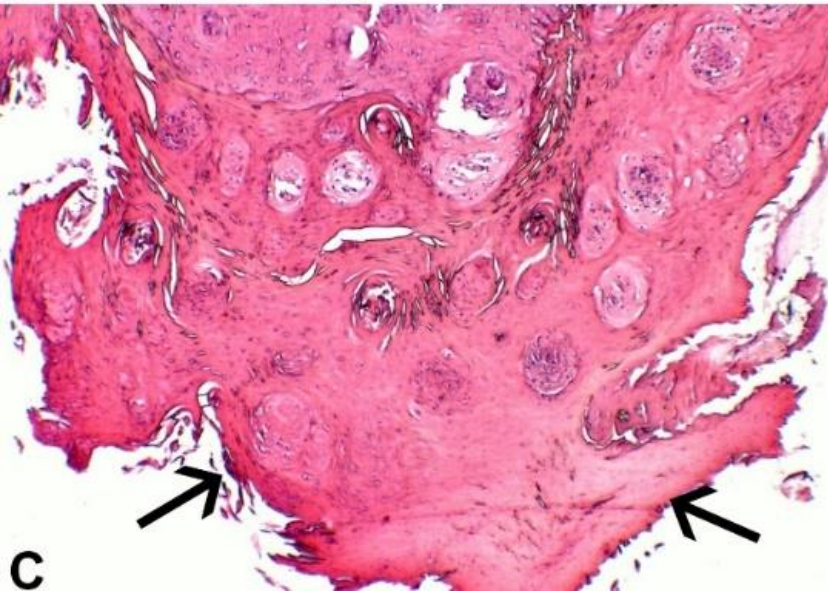

Figure 2. A. Microabscesses (arrows) and the accumulation of inflammatory cells, 4x objective, H\&E, B. Thickening of the stratum corneum (arrow) and spinosum and acanthosis 10x objective, H\&E, C. Epidermal protrusions and hyperkeratosis (arrows), 4x objective, H\&E, D. Black-stained spirochetes (arrows) among enlarged keratinocytes and inflammatory cells, 20x objective, WS. 


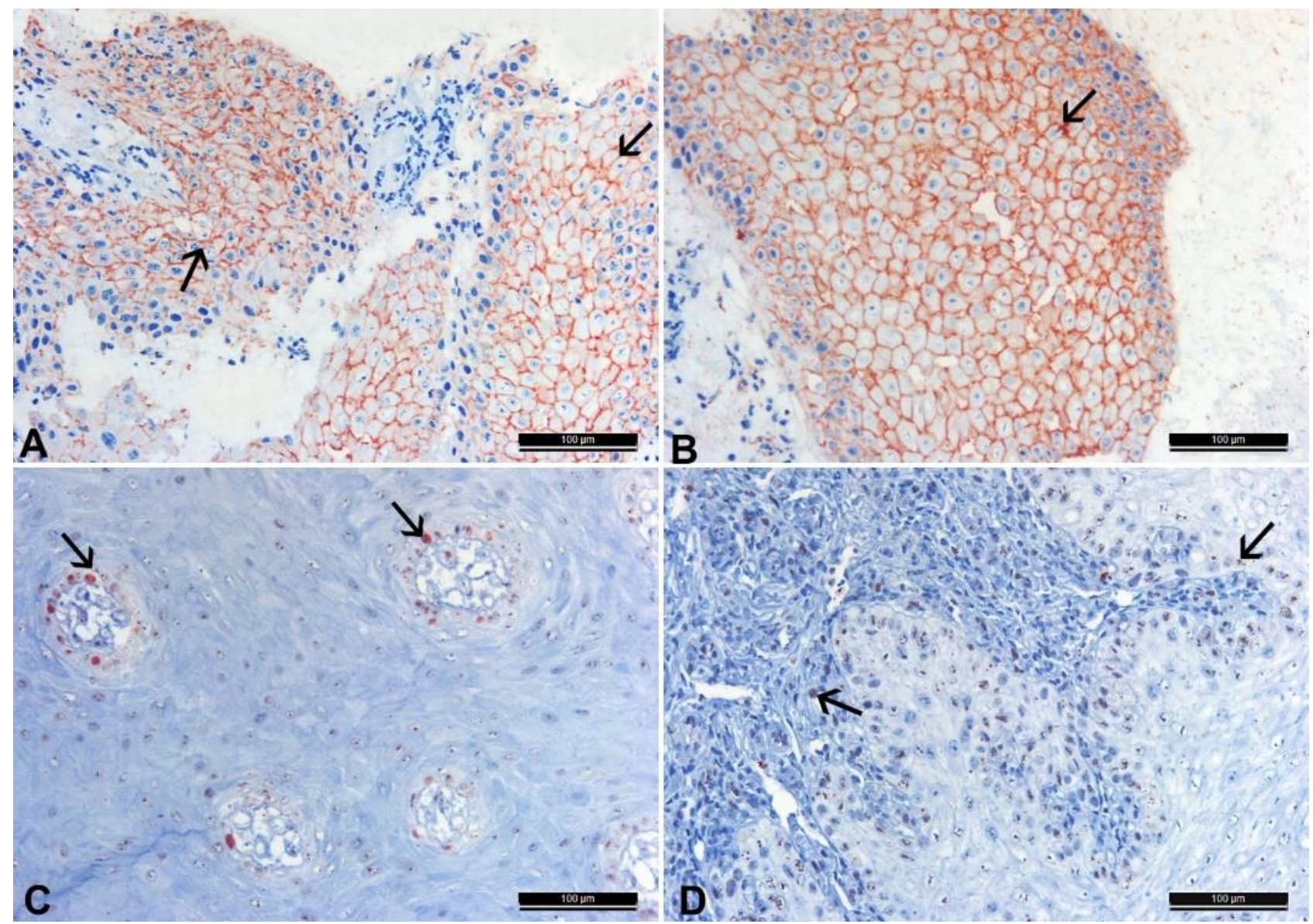

Figure 3. A-B. $\beta$-catenin (arrows) strongly positive in the cell membranes of epithelial cells, Bar: $100 \mu \mathrm{m}$, Strept ABC-P, C-D. Strong nuclear expressions in epithelial cells of PCNA (arrows), Bar: 100 $\mu \mathrm{m}$, Strept ABC-P.

\section{Discussion and Conclusion}

This disease, defined as contagious ovine digital dermatitis (CODD) in sheep (10) and contagious caprine digital dermatitis (CCDD) in goats (8), is commonly called digital dermatitis, hairy heel warts, strawberry foot, digital warts, or interdigital papillomatosis in cattle (12, 34).

Although the disease has been reported mostly in America, Canada, and England, it has been frequently seen in our country in recent years $(2,13)$. Predisposing factors such as care, shelter and feeding conditions, seasons, lactation period, mineral deficiencies, and genetic conditions play an important role in the occurrence of the disease $(12,24)$. However, it was noted that the farm conditions were not suitable in the study. Since the disease improved after the treatment, it was not thought that the disease caused by genetic conditions or mineral deficiencies occurred. The occurrence of the disease was attributed to negative environmental conditions.

While all cattle breeds were sensitive, it was reported that the disease was frequently seen in Holstein cows, and was also emphasized that the lesions were occurred in more hind legs $(5,24,29)$ as in this study.
The etiology of the disease is still exactly unknown but could be multifactorial. Bacteria may play an important role in the pathogenesis of the disease. In previous studies, it has been reported that this disease in sheep and cattle is caused by spirochetes such as Treponema vincentii, Treponema phagedenis, Treponema denticola, and Borrelia burgdorferi $(4,13,22,25)$. While the spirochetes mostly show growth in microbiology cultures, they can also be detected by immunofluorescence assay, electron microscopy, or PCR $(13,22)$. The spirochetes were detected by the WS staining in this study, but the species of spirochetes could not be determined. The spirochetes are found between the stratum spinosum and dilated keratinocytes along the dermal papilla at microscopic examination in the study. The disease should sometimes be differentiated from interdigital necrobacillosis. However, severe necrosis and edema were not observed in the feet of these animals as in necrobacillosis. In addition, differential diagnosis must be made with interdigital papilloma/papillomatosis (27). The disease is not defined as a tumor since it shows rapid spread throughout the herd and heals with antibiotics. So, it is easily distinguished from other diseases and tumors. 
Likewise, local antibiotics were used in this study. The disease showed recovery in 17/21 cattle using topical oxytetracycline hydrochloride spray, but for the other 4 cattle, lincomycin hydrochloride soluble powder was added to this spray. In this way, full recovery was occurred in all animals.

Grossly, the lesions might be usually characterized by either tumor-like papillomatosis pattern or necrotic, hemorrhagic, and ulcerative areas $(14,15,27)$. The ulcerative and hemorrhagic areas with irregular edges were accompanied in some parts by the purulent inflammation that had yellowish-whitish colored in the consistency of cream in the study. Bright red or black circular growth above the heel bulbs with edges forming hairy wart-like growths or sores were observed. In addition to these lesions, ulcerated and hemorrhagic areas were also found in the areas of the sole, toe and/or heel in some cases.

The histopathological findings in the study are compatible with the previous studies $(6,9,13,19)$. Thickening of the stratum corneum and spinosum were remarkable. In this respect, there were areas similar to papilloma. However, spirochetes detected in these areas in WS staining were diagnosed as Mortellaro disease. Necrosis, hemorragia, ulcer, acanthosis, reticular degeneration, and microabscesses were also seen in histopathological sections of some cases.

A few papers have been published about immunohistochemical $(6,9,28)$ findings of the Mortellaro disease. Cruz et al. (9) examined to only immunohistochemical findings associated with the microorganisms in the disease. Bruijnis et al. (6) used IL8 antibody to detect for corneal epithelial cells and keratocytes. In the study, $\beta$-catenin and PCNA were examined in Mortellaro disease. High expression of $\beta$ catenin and PCNA was assessed at membranes and nuclei of stratum spinosum. The high expression of PCNA showed that the mitotic activity was high and explained the formation of wart-like. In the study, it was observed that there were no alterations in the localization and expression levels of $\beta$-catenin. It was noted that $\beta$-catenin cell-cell adhesion connections were not destroyed in the disease, so this was thought to positively affect the prognosis of the disease.

In conclusion, in present study, we defined the disease pathomorphologically and showed that despite increased cell proliferation in the disease, cell-cell adhesion connections have not been lost. Although the disease does not have a poor prognosis, its economic lost is quite high and so it is known, the economical results of this disease might be much greater than the treatment costs. It could be still seen in our country, and it causes a loss of yield for the economy of country.

\section{Acknowledgements}

This study was presented as a poster in 33rd World Veterinary Congress, 27-31August 2017, Incheon, Korea.

\section{Financial Support}

This research received no grant from any funding agency/sector.

\section{Ethical Statement}

This study does not present any ethical concerns.

\section{Conflict of Interest}

The authors declared that there is no conflict of interest.

\section{References}

1. Ahmad B, Asif M, Ali A, et al (2020): Expression of Ki-67 and Beta-Catenin in pseudoepitheliomatous hyperplasia and squamous cell carcinoma in oral mucosal biopsies: an immunohistochemical study. Asian Pac J Cancer Prev, 21, 157-161.

2. Akin I, Akin T (2018): Economic impact of digital dermatitis treatment on a dairy farm: an application of the break-even analysis. Cienc Rural, 48, 1-8.

3. Akköse M, İzci C (2017): Koyun ve keçilerde digital dermatitis. Atatürk Üniversitesi Vet Bil Derg, 12, 99-110.

4. Angel JW, Crosby-Durrani HE, Duncan JS, et al (2015): Histopathological characterization of the lesions of contagious ovine digital dermatitis and immunolabelling of Treponema-like organisms. J Comp Pathol, 153, 212-226.

5. Blowey RW, Sharp MW (1988): Digital dermatitis in dairy cattle. Vet Rec, 122, 505-508.

6. Bruijnis MRN, Hogeveen H, Stassen EN (2010): Assessing economic consequences of foot disorders in dairy cattle using a dynamic stochastic simulation model. J Dairy Sci, 93, 2419-2432.

7. Bui T, Schade B, Cardiff RD, et al (2017): $\beta$-Catenin haploinsufficiency promotes mammary tumorigenesis in an ErbB2-positive basal breast cancer model. PNAS, 114, E707-E716.

8. Clegg SR, Sullivan LE, Bell J, et al (2014): The expanding host range of digital dermatitis treponemes. 55-56. In: Proceedings of the Cattle Lameness Conference, Sixways, Worcester, UK.

9. Cruz CE, Pescador CA, Nakajima Y, et al (2005): Immunopathological investigations on bovine digital epidermitis. Vet Rec, 157, 834-840.

10. Davies IH, Naylor RD, Martin PK (1999): Severe ovine foot disease. Vet Rec, 145, 646.

11. De Montpréville VT, Lacroix L, Rouleau E, et al (2020): Non-small cell lung carcinomas with CTNNB1 (betacatenin) mutations: A clinicopathological study of 26 cases. Ann Diagn Pathol, 46, 151522.

12. Demirkan İ (1997): Mortellaro hastalığl (digital dermatitis): genel perspektif. Kafkas Univ Vet Fak Derg, 3, 123-125.

13. Demirkan I, Erdoğan M, Çevik Demirkan A, et al (2018): Isolation and identification of Treponema pedis and 
Treponema phagedenis-like organisms from bovine digital dermatitis lesions found in dairy cattle in Turkey. J Dairy Sci, 101, 10317-10326.

14. Dopfer D, Koopmans A, Meijer FA, et al (1997): Histological and bacteriological evaluation of digital dermatitis in cattle, with special reference to spirochaetes and Campylobacter faecalis. Vet Rec, 140, 620-623.

15. Durgun T, İstek Ö (2004): Digital dermatitis in the cows. Fırat Üniversitesi Doğu Araştırmaları Dergisi, 2, 35-38.

16. Evans NJ, Murray RD, Carter SD (2016): Bovine digital dermatitis: current concepts from laboratory to farm. Vet J, 211, 3-13.

17. Fu X, Zhu X, Qin F, et al (2018): Linc00210 drives Wnt/ $\beta$ catenin signaling activation and liver tumor progression through CTNNBIP1-dependent manner. Mol Cancer, 17, 73.

18. Gao C, Wang Y, Broaddus R, et al (2018): Exon 3 mutations of CTNNB1 drive tumorigenesis: a review. Oncotarget, 9, 5492-5508.

19. Görgül OS, Kahraman MM, Çeçen G, et al (2002): Siğırlarda digital ve interdigital dermatitis 'lerde klinik tanı, sağaltım ve histopatolojik bulgular. J Res Vet Med, 21, 115124.

20. Hoffman A (2012): Footbaths for the treatment or control of hairy heel warts (digital dermatitis) in dairy herds: summary of seven studies. Washington State University Veterinary Medicine Extension: Washington State University.

21. Luna GL (1968): Manual of Histologic Staining Methods of the Armed Forces Institute of Pathology. McGraw Hill Book Co, New York.

22. Middelveen MJ, Burugu D, Poruri A, et al (2013): Association of spirochetal infection with Morgellons disease. F1000Research, 2, 25.

23. Naryzhny SN (2008): Proliferating cell nuclear antigen: a proteomics view. Cell Mol Life Sci, 65, 3789-3808.
24. Nowrouzian I (1994): Risk factors in the development of digital dermatitis in dairies in Tehran, Iran. Proc Int Symp Dis Ruminant Digit, 8, 155.

25. Palmer MA, O'Connell NE (2015): Digital dermatitis in dairy cows: a review of risk factors and potential sources of between-animal variation in susceptibility. Animals, 5, 512535.

26. Pignatti E, Sining L, Yuchi Y, et al (2020): Beta-Catenin causes adrenal hyperplasia by blocking zonal transdifferentiation. Cell Rep, 31, 107524.

27. Read DH, Walker RL (1998): Papillomatous digital dermatitis (footwarts) in california dairy cattle: clinical and gross pathologic findings. J Vet Diagn Invest, 10, 67-76.

28. Refaai W, Ducatelle R, Geldhof P, et al (2013): Digital dermatitis in cattle is associated with an excessive innate immune response triggered by the keratinocytes. BMC Vet Res, 9, 193.

29. Shearer JK, Amstel S van (2000): Lameness in Dairy Cattle. 1-12. In: Proceedings from 2000 Kentucky Dairy Conference, USA.

30. Shiizaki K, Kido K, Mizuta Y (2019): Insight into the relationship between arylhydrocarbon receptor and $\beta$ catenin in human colon cancer cells. PLoS ONE, 1, 1-21.

31. Strzalka W, Ziemienowicz A (2011): Proliferating cell nuclear antigen (PCNA): a key factor in DNA replication and cell cycle regulation. Ann Bot, 107, 1127-1140.

32. Sullivan LE, Evans NJ, Clegg SR, et al (2014): Digital dermatitis treponemes associated with a severe foot disease in dairy goats. Vet Rec, 176, 283.

33. Terzioğlu G, Keskin AÜ, Yanıkkaya Demirel G (2013): Hücre proliferasyonu ölçüm yöntemleri ve çeşitli ticari proliferasyon kitlerinin karşılaşıtırılması. Turk J Immunol, 1, 74-89.

34. Wilson-Welder JH, Alt DP, Nally JE (2015): Digital dermatitis in cattle: current bacterial and immunological findings. Animals, 5, 1114-1135. 